\title{
ASPECTS OF EX-SITU INTRODUCTION OF SOLANUM AETHIOPICUM L.
}

\author{
Tatiana SIRRBU, Doina ŞABAROV, Vasile SLIVCA \\ “Alexandru Ciubotaru” National Botanical Garden (Institute), \\ Chisinau, Republic of Moldova
}

\begin{abstract}
New data on the morphology, phenology, multiplication and ex-situ cultivation of the exotic species Solanum aethiopicum L. have been obtained. Under the climatic conditions of our country, it can be cultivated, as a therophyte, for its unique ornamental and, at the same time, edible fruits and foliage.
\end{abstract}

Key words: Solanum aethiopicum L., ex-situ propagation, morpho-biology, phenology, Republic of Moldova.

Solanum aethiopicum L. Cent. P1. II 10 (1756); Amoen. Acad., Linnaeus ed. 4: 307 (1759) is a therophyte from the Solanaceae family, native to Asia and tropical Africa, but successfully adapted and cultivated in other areas of the world, especially in Brazil, Australia and Southern Europe. It has various vernacular names, such as: african eggplant, bitter tomato, djakattou, nakati etc. In Southern Europe (Italy, France), it was probably introduced by the Turks earlier, but only in the nineteenth century it started being used in food, but also for ornamental purposes. In Romania, it was mentioned by Prodan (1939) as a plant cultivated in Cluj, and later attested as adventitious [1]. In the Republic of Moldova, it was not mentioned in previous botanical papers and is little known.

This crop, according to its utility, has been divided into four groups: Gilo - with edible fruits of several shapes and sizes, about $8 \mathrm{~cm}$ wide; Shum - small, branched plants with small, glabrous leaves, fruits of $1.5 \mathrm{~cm}$, inedible, very bitter; Kumba - with large, glabrous leaves and large fruits of about $10 \mathrm{~cm}$, edible; Aculeatum - plants with spiky stems and leaves, leaves covered with stellate hairs, fruit - globular, furrowed, $3-8 \mathrm{~cm}$ in diameter, inedible. It is cultivated as ornamental or as rootstock for tomatoes or eggplants, being very resistant to pathogens and pests [2].

In 2018, by Delectus Seminum, we received a sample of seeds of the abovementioned species, from the Gilo group, the 'N Goyd' cultivar, offered by the Botanical Garden of Nantes, France. At the end of April, the seeds were sown directly into the unprotected soil, obtaining 11 plants. The study on the development rate, the quality of seeds and fructification was carried out on the experimental field of the "Ornamental Plants" Laboratory, in the collection of annual plants and under laboratory conditions. The local pedoclimatic conditions were suitable for the small population, obviously with the observance of all agrotechnical procedures (irrigation, applying fertilizers etc.).

The plants of this cultivar are erect, strongly branched, growing about $150 \mathrm{~cm}$ tall. Stems - glossy, glabrous, cylindrical and rigid: almost woody at the base. The main stem is about $2 \mathrm{~cm}$ in diameter at the base of the bush, towards the top $-1 \mathrm{~cm}$. There are ramifications up to the third order. The leaves are entire, lobed, dark green, slightly pubescent, large ( $40.5 \mathrm{~cm}$ long together with the petiole), alternate at the base of the plant and opposite towards the top (18.6 cm long). A shoot has over 30 leaves. The lush foliage gives the plant an elegant and showy appearance. The flowers are white, actinomorphic, 
with 5-6 petals, with upper ovary, forming a raceme of 4-6-8 units. After pollination, the flowers become bell-shaped. The diameter of an open flower is $1.5-2.5 \mathrm{~cm}$. The size of the sepals $-0.3 \times 0.7 \mathrm{~cm}$; petals $-0.4 \times 1.0 \mathrm{~cm}$; stamens $-0.5 \times 0.1 \mathrm{~cm}$; pistil $-0.1 \times 0.5 \mathrm{~cm}$; upper ovary $-0.4 \times 0.3 \mathrm{~cm}$. About 35-50 flowers can be formed on a shoot. About $50 \%$ of them bear fruit. The fruit is a red or orange berry, which under the conditions of our country reaches maturity in August-September. Flowering and fruiting continue until late autumn. The largest fruits are about $10 \mathrm{~cm}$ in diameter and weigh up to $120 \mathrm{~g}$. The fruits, close to maturity, are greenish-orange, and the mature ones - orangered. Their weight is about $50-70 \mathrm{~g}$ and the diameter $-5-6 \mathrm{~cm}$. There are about 800 seeds in a ripe fruit. About $800 \mathrm{~g}$ of fruits were collected from a plant. The seeds are $3 \mathrm{~mm}$ in diameter, cream-white, with epigeal germination. In the field, the seedlings emerge on the 10th day after sowing. Under controlled conditions, at $\mathrm{T}^{\circ} \mathrm{C}=+22^{\circ} \mathrm{C}-$ on the 4 th -7 th day, the germination rate being $21 \%$. The small percentage of seed germination has also been mentioned by other authors [2].

The seedling phase lasts about 40 days. In the middle of June, the floral primordia appear, thus being initiated the generative period. The optimum temperature for the normal development and growth of $S$. aethiopicum is about $+25^{\circ} \mathrm{C}$. The night temperature is also important; it must not be lower than $+18^{\circ} \mathrm{C}$. The flowering phase begins in early July. The fruits ripen in the middle of August ( 82 days). Flowering and fruiting are staggered. Thus, the plants have a long growing season (about 180 days). With the decrease of night and day temperatures, and with the obvious thermal gap, the appearance of the plant gradually changes, losing its decorativeness. But the fall of the leaves reveals the beauty of the red-orange fruits, which give the plant an unusual appearance, due to which it is also called "Pumpkin Tree". In their homeland, these plants have been commonly used for centuries to prepare food, for medicinal and ornamental purposes. The fruits are eaten boiled, steamed, pickled and fried, mixed with other vegetables. The young leaves are used in soups, salads. The entire aerial part of the plant contains many bioactive substances: beta-carotene, vitamin E, ascorbic acid, calcium, iron. The leaves also contain alkaloids with anti-inflammatory and immunostimulatory properties, and the fruits and roots have sedative, analgesic and hypotensive effects [2]. $S$. aethiopicum is a new exotic species for our country, with interesting properties and uses, for researchers and for professional and amateur growers, collectors, local breeders of ornamental plants.

The research was conducted within the project 20.80009.7007.14 „, Research on mobilizing plant diversity with ornamental potential for ex-situ conservation”.

\section{BIBLIOGRAPHY}

1. Sîrbu C., Oprea A. Plante adventive în flora României. Ed. Ioan I. de la Brad. Iaşi, 2011. P. 333.

2. https://avrdc.org/african-eggplant-solanum-aethiopicum. (vizitat 24.09.20).

3. http://www.theplantlist.org/1.1/browse/A/Solanaceae/Solanum/.(vizitat 19.09.20). 